\title{
Spectroscopic, Magnetic and Crystal Structure Analysis of Diammine-bis(2,6-dibromo-4-chlorophenolato-O)copper(II)
}

\author{
Gülsün Gökağaça ${ }^{\mathrm{a}}$, Leyla Tatar Yildirim ${ }^{\mathrm{b}}$, Muammer Sonsuz ${ }^{\mathrm{a}}$, and Fatih Şen ${ }^{\mathrm{a}}$ \\ ${ }^{a}$ Middle East Technical University, Department of Chemistry, 06531 Ankara, Turkey \\ ${ }^{\mathrm{b}}$ Hacettepe University, Department of Engineering Physics, Beytepe 06800, Ankara, Turkey \\ Reprint requests to Assoc. Prof. Dr. G. Gökağaç. E-mail: ggulsun@metu.edu.tr
}

Z. Naturforsch. 60b, 543 - 547 (2005); received August 11, 2004

The $\left[\mathrm{Cu}\left(\mathrm{C}_{6} \mathrm{H}_{2} \mathrm{Br}_{2} \mathrm{ClO}\right)_{2}\left(\mathrm{NH}_{3}\right)_{2}\right]$ complex was synthesized and characterized by $\mathrm{XRD}, \mathrm{UV} / \mathrm{vis}$, FTIR, DSC, elemental analysis and magnetic susceptibility measurements. The structural analysis of the title complex indicated that it is a monomeric centrosymmetric compound which crystallizes in the monoclinic system, $P 2_{1} / c$, and has a trans-planar $\mathrm{CuO}_{2} \mathrm{~N}_{2}$ coordination $[\mathrm{Cu}-\mathrm{O}$ 1.940(5) and $\mathrm{Cu}-\mathrm{N}$ 1.978(7) $\AA$ ]. In the coordination sphere of the $\mathrm{Cu}$ atom, there are long range interactions with $\mathrm{Br} 2$ and the centrosymetrically related $\mathrm{Br} 2 \mathrm{i}(\mathrm{i}:-x,-y,-z)$ atoms $[\mathrm{Cu}-\mathrm{Br} 2: 3.079(2) \AA]$, resulting in a tetragonally elongated octahedral structure for the $\mathrm{CuO}_{2} \mathrm{~N}_{2} \mathrm{Br}_{2}$ coordination. The molecules form one-dimensional chains along the $x$-axis of the unit cell held together by intermolecular hydrogen bonds.

Key words: UV/vis, FTIR, DSC, Crystal Structure, Cu(II) Complex, Magnetic Susceptibility

\section{Introduction}

Preparation of polymers from inorganic complexes is a very interesting subject in inorganic and polymer chemistry. For instance, flame-retarding polymers, poly(dihalophenolates), can be prepared with $\mathrm{CuL}_{2}$ (THP) $)_{2}$ complexes, where $\mathrm{L}$ is pyridine, ethylenediamine, 2,2'-dipyridyl, or ammonia, and THP is 2,4,6-trichloro-phenolato, 2,4,6-tribromo-phenolato, 4-chloro-2,6-dibromo-phenolato or 4-fluoro-2,6dibromo-phenolato. There are several criteria which affect the molecular weight and the structure of the polymers. These are the structure of the complexes and the kind of the ligands [1-5]. Therefore, in this study, the $\mathrm{Cu}(\mathrm{II})$ complex $\left[\mathrm{Cu}\left(\mathrm{C}_{6} \mathrm{H}_{2} \mathrm{ClBr}_{2} \mathrm{O}\right)_{2}\left(\mathrm{NH}_{3}\right)_{2}\right]$ has been prepared and characterized by structural, spectroscopic, thermal, and elemental analysis, and magnetic susceptibility measurements. The polymerization study with the title complex is currently under investigation.

\section{Experimental Section}

Preparation of potassium 2,6-dibromo-4-chloro-phenolate

4-Chlorophenol was brominated by adding a solution containing $0.1 \mathrm{M}$ bromine and $0.15 \mathrm{M} \mathrm{KBr}$ in $150 \mathrm{ml}$ of distilled water to another solution containing stochiometric amounts of the phenol in the minimum amount of ethanol very slowly.
The solution with a white precipitate was cooled in an ice bath for 20 minutes, filtered and then dried in a vacuum oven. The structure and the purity of the product were established by the ${ }^{1} \mathrm{H}$ NMR spectrum [6].

\section{Preparation of the diammine-bis(2,6-dibromo-4-chloro- phenolato-O)copper(II) complex}

An aqueous solution $(15 \mathrm{ml})$ of potassium 2,6-dibromo4-chloro-phenolate was prepared by adding an excess of $\mathrm{KOH}(0.12 \mathrm{~g}, 3 \mathrm{mmol})$ dissolved in water $(10 \mathrm{ml})$ to $2,6-$ dibromo-4-chloro-phenol (0.43 g, $1.5 \mathrm{mmol})$ solution dissolved in water $(5 \mathrm{ml})$. This solution was added dropwise to a concentrated aqueous solution $(5 \mathrm{ml})$ of $\mathrm{CuSO}_{4}(0.12 \mathrm{~g}$, $0.75 \mathrm{mmol}$ ) with stirring. Initially, the formation of a dark brown precipitate was observed. Upon addition of all 2,6dibromo-4-chloro-phenolate solution, the dark brown precipitate turned to a light blue color. Concentrated ammonia $(13 \mathrm{ml}, 0.695 \mathrm{~mol})$ and water $(60 \mathrm{ml})$ were added to this mixture until the light blue precipitate dissolved to give a clear dark blue solution. Upon leaving this solution in a dark place for several days, dark brown crystals were formed. These crystals were collected, washed with cold water and dried in a vacuum overnight $[2,3]$.

\section{Structure determination}

To determine the crystal structure of the title compound $\mathrm{X}$-ray diffraction data were collected at room temperature with graphite-monochromated $\mathrm{Mo}-\mathrm{K}_{\alpha}$ radiation on an Enraf- 
Table 1. Summary of crystallographic data.

\begin{tabular}{|c|c|}
\hline Formula & {$\left[\mathrm{Cu}\left(\mathrm{C}_{6} \mathrm{H}_{2} \mathrm{Br}_{2} \mathrm{ClO}\right)_{2}\left(\mathrm{NH}_{3}\right)_{2}\right]$} \\
\hline Fw & 668.27 \\
\hline Wavelength $[\AA]$ & 0.71073 \\
\hline Temperature $\left[{ }^{\circ} \mathrm{C}\right]$ & 25 \\
\hline Crystal shape & needle \\
\hline Crystal color & dark-brown \\
\hline Crystal size $\left[\mathrm{mm}^{3}\right]$ & $0.40 \times 0.20 \times 0.15$ \\
\hline Crystal system & monoclinic \\
\hline Space group & $P 2_{1} / n$ (no. 14$)$ \\
\hline$a[\AA]$ & $4.887(3)$ \\
\hline$b[\AA]$ & $12.760(8)$ \\
\hline$c[\AA]$ & $15.243(4)$ \\
\hline$\beta$ & $92.77(3)$ \\
\hline$V\left[\AA^{3}\right]$ & $949.4(9)$ \\
\hline$Z$ & 2 \\
\hline$D_{\text {calc }}\left[\mathrm{g} / \mathrm{cm}^{3}\right]$ & 2.338 \\
\hline Absorption coefficent $\left[\mathrm{mm}^{-1}\right]$ & 9.856 \\
\hline$F(000)$ & 630 \\
\hline Scan method & $\omega / 2 \theta$ \\
\hline $2 \theta_{\max }\left[{ }^{\circ}\right]$ & 52.6 \\
\hline Index range & $\begin{aligned} 0 & \leq h \leq 6, \\
0 & \leq k \leq 15, \\
-18 & \leq l \leq 18\end{aligned}$ \\
\hline No. of reflections collected & 2135 \\
\hline No. of reflections unique & 1909 \\
\hline No. of variables & 106 \\
\hline Max shift/esd & 0.992 \\
\hline Phasing method & direct methods \\
\hline$R / R w(\%)$ & $0.0543 / 0.1305$ \\
\hline
\end{tabular}

Nonius CAD4 diffractometer [7]. The cell parameters were determined from a least-squares refinement of 25 centred reflections in the range of $8.45 \leq \theta \leq 18.84^{\circ}$. Cell refinement was carried out using CAD-4 EXPRESS. During data collection, three standard reflections were periodically measured every 120 minutes, showing no significant intensity variation. Data reduction was carried out using SHELXL97 [8].

The structure was solved by direct methods using the program SHELXS97 [8] in the WinGX package [9]. $\psi$-Scan absorption correction was applied $\left(T_{\min }=0.108, T_{\max }=\right.$ 0.228). A full-matrix least-squares refinement on $F^{2}$ was done. For all non-hydrogen atoms anisotropic displacement parameters were refined. All hydrogen atoms were placed geometrically and a riding model was used with $U_{\text {iso }}(\mathrm{H})=1.2$ $U_{\text {eq }}(\mathrm{C})$ and $U_{\text {iso }}(\mathrm{H})=1.5 U_{\text {eq }}(\mathrm{N})$. Electron density synthesis with coefficients $F \mathrm{o}-F \mathrm{c}$ : A positive residual electron density of $1.21 \mathrm{e} / \AA^{3}$ was observed at a distance of $0.95 \AA$ from the $\mathrm{Cu}$ atom and negative residual electron density of $-1.29 \mathrm{e} / \AA^{3}$ at a distance of $1.01 \AA$ from the Br1 atom. The data collection details, crystal data and refinement parameters are summarised in Table 1 . The atomic coordinates and isotropic displacement parameters are listed in Table 2, selected bond lengths and angles are given in Table 3 and the ORTEP drawing is given in Fig. 1. Displacements ellipsoids are drawn at the $50 \%$ probability level and $\mathrm{H}$ atoms are shown as small circles with arbitrary radii.
Table 2. Atomic coordinates and equivalent isotropic displacement parameters for non-hydrogen atoms.

\begin{tabular}{llcll}
\hline Atom & \multicolumn{1}{c}{$x$} & \multicolumn{1}{c}{$y$} & \multicolumn{1}{c}{$U_{\mathrm{eq}}\left[\AA^{2}\right]$} \\
\hline $\mathrm{Cu}$ & 0 & 0 & 0 & $0.0294(4)$ \\
$\mathrm{O}$ & $0.1796(11)$ & $-0.0134(5)$ & $-0.1102(3)$ & $0.0364(15)$ \\
$\mathrm{N}$ & $0.2881(14)$ & $-0.0902(6)$ & $0.0558(5)$ & $0.0395(18)$ \\
$\mathrm{Br} 1$ & $0.3415(2)$ & $0.12859(9)$ & $-0.25975(7)$ & $0.0563(4)$ \\
$\mathrm{Br} 2$ & $-0.2272(2)$ & $-0.19807(7)$ & $-0.09304(6)$ & $0.0448(3)$ \\
$\mathrm{Cl}$ & $-0.3637(8)$ & $-0.1304(3)$ & $-0.44875(18)$ & $0.0850(11)$ \\
$\mathrm{C} 1$ & $0.0509(17)$ & $-0.0378(7)$ & $-0.1852(5)$ & $0.033(2)$ \\
$\mathrm{C} 2$ & $0.0994(18)$ & $0.0119(7)$ & $-0.2643(5)$ & $0.037(2)$ \\
$\mathrm{C} 3$ & $-0.021(2)$ & $-0.0134(8)$ & $-0.3440(6)$ & $0.048(3)$ \\
$\mathrm{C} 4$ & $-0.207(2)$ & $-0.0939(8)$ & $-0.3472(6)$ & $0.052(3)$ \\
$\mathrm{C} 5$ & $-0.2723(19)$ & $-0.1471(8)$ & $-0.2731(6)$ & $0.044(2)$ \\
$\mathrm{C} 6$ & $-0.1431(18)$ & $-0.1203(7)$ & $-0.1952(5)$ & $0.034(2)$ \\
$\mathrm{H} 1 \mathrm{~A}$ & 0.2562 & -0.0988 & 0.1123 & 0.059 \\
$\mathrm{H} 1 \mathrm{~B}$ & 0.4509 & -0.06 & 0.0509 & 0.059 \\
$\mathrm{H} 1 \mathrm{C}$ & 0.2868 & -0.1523 & 0.0292 & 0.059 \\
$\mathrm{H} 3$ & 0.022 & 0.0227 & -0.3945 & 0.057 \\
$\mathrm{H} 5$ & -0.402 & -0.2005 & -0.276 & 0.053 \\
\hline
\end{tabular}

Table 3. Selected bond lengths $(\AA)$ and bond angles $\left(^{\circ}\right)$.

\begin{tabular}{lrlr}
\hline $\mathrm{Cu}-\mathrm{O}$ & $1.940(5)$ & $\mathrm{Cu}-\mathrm{N}$ & $1.978(7)$ \\
$\mathrm{Cu}-\mathrm{Br} 2$ & $3.079(2)$ & $\mathrm{Br} 1-\mathrm{C} 2$ & $1.901(9)$ \\
$\mathrm{Br} 2-\mathrm{C} 6$ & $1.908(8)$ & $\mathrm{Cl}-\mathrm{C} 4$ & $1.757(9)$ \\
$\mathrm{O}-\mathrm{C} 1$ & $1.315(9)$ & & \\
$\mathrm{O}-\mathrm{Cu}-\mathrm{N}$ & $88.8(3)$ & $\mathrm{O}-\mathrm{Cu}-\mathrm{N}$ & $91.2(3)$ \\
$\mathrm{Br} 2-\mathrm{Cu}-\mathrm{O}$ & $72.4(2)$ & $\mathrm{Br} 2-\mathrm{Cu}-\mathrm{N}$ & $87.4(2)$ \\
$\mathrm{C} 1-\mathrm{O}-\mathrm{Cu}$ & $123.8(5)$ & $\mathrm{C} 3-\mathrm{C} 2-\mathrm{Br} 1$ & $117.3(7)$ \\
$\mathrm{C} 1-\mathrm{C} 2-\mathrm{Br} 1$ & $117.2(7)$ & $\mathrm{C} 5-\mathrm{C} 6-\mathrm{Br} 2$ & $118.2(7)$ \\
$\mathrm{C} 1-\mathrm{C} 6-\mathrm{Br} 2$ & $117.9(6)$ & $\mathrm{C} 5-\mathrm{C} 4-\mathrm{Cl}$ & $119.1(8)$ \\
$\mathrm{C} 3-\mathrm{C} 4-\mathrm{Cl}$ & $119.4(8)$ & & \\
\hline
\end{tabular}

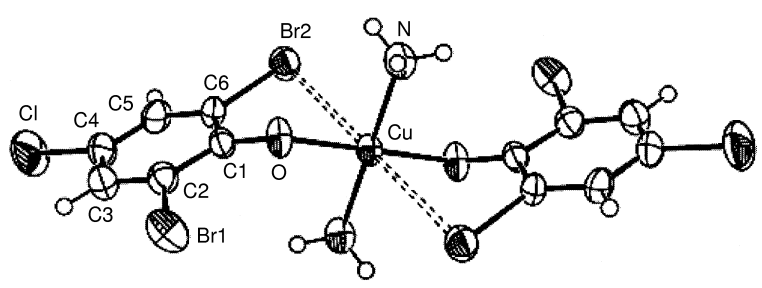

Fig. 1. ORTEP [10] drawing of the title molecule with the atom numbering scheme.

A differential scanning calorimeter, DSC, was used in order to investigate the thermal behaviour of the complex. The thermogram was taken with a heating of $1{ }^{\circ} \mathrm{C} / \mathrm{min}$ under atmospheric conditions by a Dupont thermal analyst 2000 DSC 910S model differential scanning calorimeter. At $170.02{ }^{\circ} \mathrm{C}$, a sharp exothermic peak was observed.

\section{Results and Discussion}

\section{Crystal structure}

We previously reported the structures of the isostructural complexes $\left[\mathrm{Cu}\left(\mathrm{C}_{6} \mathrm{H}_{2} \mathrm{Br}_{3} \mathrm{O}\right)_{2}\left(\mathrm{NH}_{3}\right)_{2}\right]$ [3] and $\left[\mathrm{Cu}\left(\mathrm{C}_{6} \mathrm{H}_{2} \mathrm{Cl}_{3} \mathrm{O}\right)_{2}\left(\mathrm{NH}_{3}\right)_{2}\right]$ [2]. In these complexes, the 
Table 4. Coordination bond lengths $(\AA)$ and angles $\left(^{\circ}\right)$ for three isostructural copper complexes.

\begin{tabular}{lccc}
\hline & $\begin{array}{c}{\left[\mathrm{Cu}\left(\mathrm{C}_{6} \mathrm{H}_{2-}\right.\right.} \\
\left.\left.\mathrm{Cl}_{3} \mathrm{O}\right)_{2}\left(\mathrm{NH}_{3}\right)_{2}\right]\end{array}$ & $\begin{array}{c}{\left[\mathrm{Cu}\left(\mathrm{C}_{6} \mathrm{H}_{2-}\right.\right.} \\
\left.\left.\mathrm{Br}_{3} \mathrm{O}\right)_{2}\left(\mathrm{NH}_{3}\right)_{2}\right]\end{array}$ & $\begin{array}{c}{\left[\mathrm{Cu}\left(\mathrm{C}_{6} \mathrm{H}_{2}-\right.\right.} \\
\left.\left.\mathrm{Br}_{2} \mathrm{ClO}\right)_{2}\left(\mathrm{NH}_{3}\right)_{2}\right]\end{array}$ \\
\hline $\mathrm{Cu}-\mathrm{Br}$ & - & $3.129(1)$ & $3.079(2)$ \\
$\mathrm{Cu}-\mathrm{Cl}$ & $2.982(1)$ & - & - \\
$\mathrm{Cu}-\mathrm{O}$ & $1.946(2)$ & $1.943(5)$ & $1.940(5)$ \\
$\mathrm{Cu}-\mathrm{N}$ & $1.984(2)$ & $1.977(6)$ & $1.978(7)$ \\
$\mathrm{O}-\mathrm{Cu}-\mathrm{N}$ & $90.66(9)$ & $89.1(2)$ & $88.8(3)$ \\
$\mathrm{Br}-\mathrm{Cu}-\mathrm{O}$ & - & $70.9(2)$ & $72.4(2)$ \\
$\mathrm{Br}-\mathrm{Cu}-\mathrm{N}$ & - & $87.1(2)$ & $87.4(2)$ \\
$\mathrm{Cl}-\mathrm{Cu}-\mathrm{O}$ & $71.20(7)$ & - & - \\
$\mathrm{Cl}-\mathrm{Cu}-\mathrm{N}$ & $86.99(8)$ & - & - \\
\hline
\end{tabular}

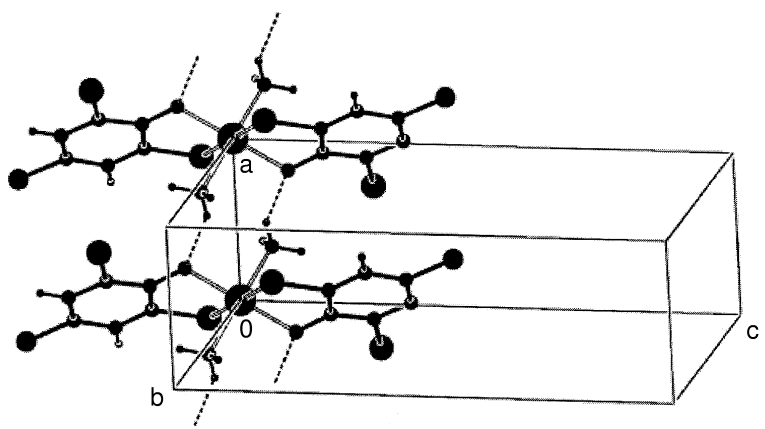

Fig. 2. Hydrogen bonding geometry and the molecular packing.

copper atom is located at the inversion centre. The coordination around the $\mathrm{Cu}$ atom is a tetragonally elongated octahedron involving centrocymetrically related $\mathrm{O}$ and $\mathrm{N}$ atoms from THP molecules in the equatorial plane, and $\mathrm{Br}$ and $\mathrm{Cl}$ atoms with secondary interaction in the axial positions, respectively. In the present study, $\left[\mathrm{Cu}\left(\mathrm{C}_{6} \mathrm{H}_{2} \mathrm{Br}_{2} \mathrm{ClO}\right)_{2}\left(\mathrm{NH}_{3}\right)_{2}\right]$ is reported. The coordination sphere of the $\mathrm{Cu}$ atom is similar to that of the isostructural complexes (Table 3). A comparison of the bond lengths and angles is given in Table 4 for the three isostructural complexes. The remarkable similarity of the three structures is obvious.

The dihedral angle between the $\mathrm{O} / \mathrm{Cu} / \mathrm{N}$ plane and the least-squares plane defined by the six-membered ring (C1...C6) is $80.8(2)^{\circ}$ (Fig. 1). This is slightly smaller than the corresponding values of $81.7(1)^{\circ}$ and 82.6(2) ${ }^{\circ}$ observed in the Cu-tribromophenolate [3] and $\mathrm{Cu}$-trichlorophenolate [2] complexes, respectively. $\mathrm{The} \mathrm{O} / \mathrm{Cu} / \mathrm{Br} 2$ and $\mathrm{N} / \mathrm{Cu} / \mathrm{Br} 2$ planes are almost perpendicular to each other. The dihedral angle between these two planes is $89.5(2)^{\circ}$. The $\mathrm{Br} 2 / \mathrm{Cu} / \mathrm{O} / \mathrm{C} 1 / \mathrm{C} 6$ ring has an envelope conformation.

The hydrogen bonding and molecular packing geometry of the title molecule was calculated with PLATON [11]. There is an intermolecular $\mathrm{N}-\mathrm{H} 1 \mathrm{~B} \ldots \mathrm{O}^{\mathrm{ii}}$ hydrogen bond with $\mathrm{D} \ldots \mathrm{A}$ and $\mathrm{H} . . \mathrm{A}$ distances of 2.999(9) and $2.19 \AA$, respectively and a D-H...A angle of $150.8(5)^{\circ}$ [symmetry code ii: $1-x,-y,-x]$. As shown in Fig. 2, the complexes form hydrogen bonded polymeric bands of $\left[\mathrm{Cu}\left(\mathrm{C}_{6} \mathrm{H}_{2} \mathrm{Br}_{2} \mathrm{ClO}\right)_{2}\left(\mathrm{NH}_{3}\right)_{2}\right]$ molecules which are lined up along the [100] direction like as the isostructural complexes $[2,3]$. There is a difference in the hydrogen bonding geometry between the title molecule and the isostructural molecules reported previously $\left[\mathrm{Cu}\left(\mathrm{C}_{6} \mathrm{H}_{2} \mathrm{Br}_{3} \mathrm{O}\right)_{2}\left(\mathrm{NH}_{3}\right)_{2}\right]$ [3] and $\left[\mathrm{Cu}\left(\mathrm{C}_{6} \mathrm{H}_{2} \mathrm{Cl}_{3} \mathrm{O}\right)_{2}\left(\mathrm{NH}_{3}\right)_{2}\right]$ [2]. These molecules have two intermolecular hydrogen bonds, but $\left[\mathrm{Cu}\left(\mathrm{C}_{6} \mathrm{H}_{2} \mathrm{Br}_{2} \mathrm{ClO}\right)_{2}\left(\mathrm{NH}_{3}\right)_{2}\right]$ has only one. However, all these molecules show a similar molecular packing geometry. The shortest intermolecular contact less than the sum of the van der Waals Radii was observed between $\mathrm{Cu}$ and $\mathrm{H}_{1} \mathrm{~B}^{\mathrm{ii}}[2.9311 \ll 3.52 \AA]$.

\section{UV/vis}

The UV/vis electronic spectra of the title complex and of the ligand, 2,6-dibromo-4-chlorophenolate, and detailed data are given in Figs 3, 4 and Table 5, respectively. The complex has intense peaks at 208, 290 and $296 \mathrm{~nm}$, shoulders at 222 and $318 \mathrm{~nm}$, and a broad peak at $410 \mathrm{~nm}$. The ligand has intense peaks at 208, $290,296 \mathrm{~nm}$ and a shoulder at $222 \mathrm{~nm}$. It is well known that $\pi$ electrons of a phenol give characteristic ultraviolet absorption bands between 200 and $300 \mathrm{~nm}$ [12]. The ligand displays four absorption bands which might originate from $\pi \rightarrow \pi^{*}$ transitions. Their peak intensities are about half as large as the corresponding peaks of the complex. The shoulder at $318 \mathrm{~nm}$ and a broad peak at $410 \mathrm{~nm}$ for the title complex might be due to

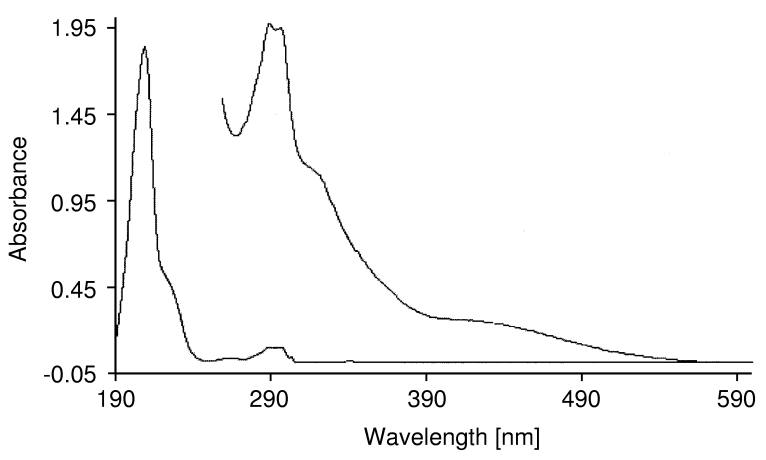

Fig. 3. UV/vis spectrum of the complex in an acetonitrile solvent. Curve 1: $3.5 \times 10^{-4} \mathrm{M}$; curve $2: 2.02 \times 10^{-5} \mathrm{M}$ in $\left[\mathrm{Cu}\left(\mathrm{C}_{6} \mathrm{H}_{2} \mathrm{ClBr}_{2} \mathrm{O}\right)_{2}\left(\mathrm{NH}_{3}\right)_{2}\right]$. 
Table 5. UV/vis data $\lambda_{\max }[\mathrm{nm}]\left(\varepsilon\left[1 / \mathrm{mol}^{-1} \mathrm{~cm}^{-1}\right]\right)$ of the title complex and the ligand.

\begin{tabular}{ll}
\hline$\left[\mathrm{Cu}\left(\mathrm{C}_{6} \mathrm{H}_{2} \mathrm{ClBr}_{2} \mathrm{O}\right)_{2}\left(\mathrm{NH}_{3}\right)_{2}\right]$ & {$\left[\mathrm{C}_{6} \mathrm{H}_{2} \mathrm{ClBr}_{2} \mathrm{O}\right]^{-} \mathrm{K}^{+}$} \\
\hline $208(89100)$ & $208(44500)$ \\
$222(25150)(\mathrm{sh})$ & $222(12500)(\mathrm{sh})$ \\
$290(5810)$ & $290(2900)$ \\
$296(6050)$ & $296(3000)$ \\
$318(2990)(\mathrm{sh})$ & \\
$410(980)(\mathrm{broad})$ & \\
\hline
\end{tabular}

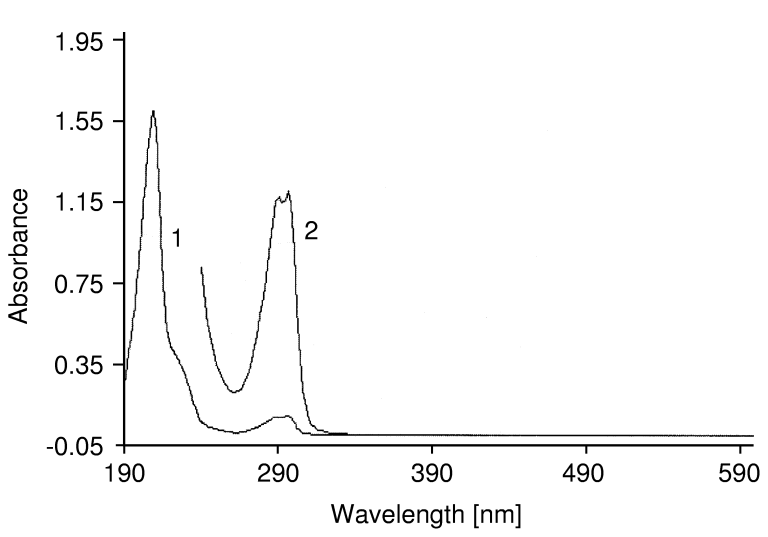

Fig. 4. UV/vis spectrum of the ligand in an acetonitrile solvent. Curve 1: $3.6 \times 10^{-5} \mathrm{M} \mathrm{K}\left[\mathrm{C}_{6} \mathrm{H}_{2} \mathrm{ClBr}_{2} \mathrm{O}\right]$; curve 2: $4.14 \times 10^{-4} \mathrm{M}$ in $\left.\mathrm{K}_{[} \mathrm{C}_{6} \mathrm{H}_{2} \mathrm{ClBr}_{2} \mathrm{O}\right]$.

d-d transitions and/or ligand to metal charge transfer transitions in the complex. The color of the complex in an acetonitrile solution is yellow and one of the d-d transitions is observed in the violet region of the spectrum as it is expected.

\section{IR data}

The FTIR spectrum of the $\mathrm{Cu}(\mathrm{II})$ complex is given in Fig. 5 and the characteristic bands are:

$\gamma_{(\mathrm{N}-\mathrm{H})}$ and $\gamma_{(\mathrm{C}-\mathrm{H} \text { aromatic })}=3500-3000 \mathrm{~cm}^{-1}$, $\gamma_{(\text {aromatic rings })}=1602 \mathrm{~cm}^{-1}, \quad \gamma_{(\mathrm{C}=\mathrm{C} \text { ring stretchings })}=$ $1460-1260 \mathrm{~cm}^{-1}, \quad \gamma_{(\mathrm{C}-\mathrm{O})}=1225 \mathrm{~cm}^{-1}$, $\gamma_{(\mathrm{C}-\mathrm{H} \text { bending })}=855 \mathrm{~cm}^{-1}, \gamma_{(\mathrm{C}-\mathrm{Cl})}=800-650 \mathrm{~cm}^{-1}$, $\gamma_{(\mathrm{C}-\mathrm{Br})}=750-600 \mathrm{~cm}^{-1}$ and $\gamma_{(\mathrm{C}=\mathrm{C} \text { bending })}=$ $438 \mathrm{~cm}^{-1}[13,14]$.

\section{Magnetic susceptibility}

Magnetic susceptibility measurement was performed at room temperature using a Sherwood magnetic susceptibility balance. The magnetic moment of

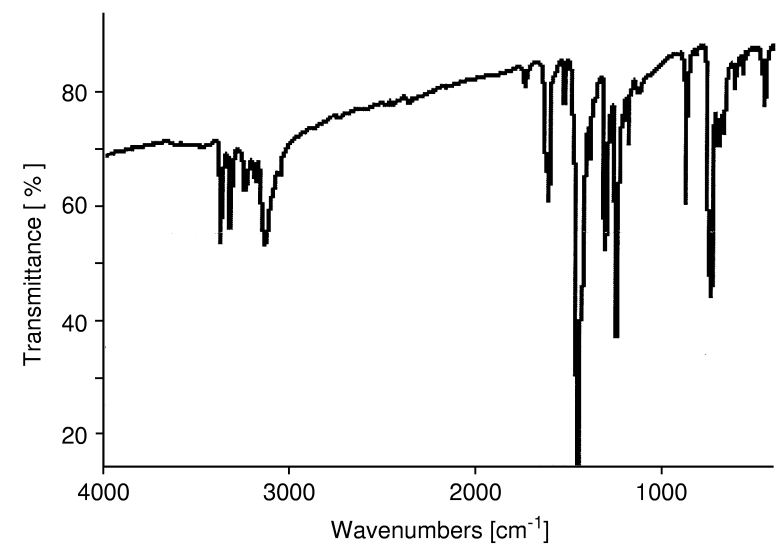

Fig. 5. FTIR spectrum of $\left[\mathrm{Cu}\left(\mathrm{C}_{6} \mathrm{H}_{2} \mathrm{ClBr}_{2} \mathrm{O}\right)_{2}\left(\mathrm{NH}_{3}\right)_{2}\right]$.

the title complex was found to be $1.85 \mu \mathrm{B}$. The calculated spin-only magnetic moment $(\mu / \mu \mathrm{B})$ for a single unpaired electron complexes is $1,73 \mu \mathrm{B}$. The difference might be due to spin-orbit coupling [15] which was also observed for the $\left[\mathrm{Cu}\left(\mathrm{C}_{6} \mathrm{H}_{2} \mathrm{I}_{3} \mathrm{O}\right)_{2}\left(\mathrm{NH}_{3}\right)_{2}\right]$ complex [13].

\section{Conclusions}

The crystal structure of $\left[\mathrm{Cu}\left(\mathrm{C}_{6} \mathrm{H}_{2} \mathrm{Br}_{2} \mathrm{ClO}\right)_{2}\left(\mathrm{NH}_{3}\right)_{2}\right]$ has been determined by $\mathrm{X}$-ray diffraction. It crystallizes in the monoclinic system and shows a transplanar $\mathrm{CuO}_{2} \mathrm{~N}_{2}$ coordination sphere, with the fifth and sixth coordination sites occupied by $\mathrm{Br}$ atoms of the phenoxide ions to form a tetragonally elongated octahedral structure. Intermolecular hydrogen bonds hold the complex molecules together in a one-dimensional chain.

The complex $\left[\mathrm{Cu}\left(\mathrm{C}_{6} \mathrm{H}_{2} \mathrm{Br}_{2} \mathrm{ClO}\right)_{2}\left(\mathrm{NH}_{3}\right)_{2}\right]$ has intense UV/vis absorption peaks at 208, 290 and $296 \mathrm{~nm}$, and a shoulder at $222 \mathrm{~nm}$ tentitavely assigned to $\pi \rightarrow$ $\pi^{*}$ transitions of the 2,6-dibromo-4-chloro-phenolate ligand, and a shoulder at $318 \mathrm{~nm}$ and a broad peak at $410 \mathrm{~nm}$ probably due to d-d transitions and/or ligand to metal charge transfer transitions. The magnetic susceptibility data indicate that the title complex has a $d^{9}$ electron configuration with one unpaired electron as expected.

\section{Acknowledgements}

This work was financially supported by the Scientific Research Project (Bilimsel Araştırma Projesi) of Middle East Technical University, Turkey, Grant No: BAP-2003-07-0200-95. 
[1] M. Pulat, E. Çakir, Reactive and Functional Polymers, 46(2), 117 (2000).

[2] G. Gökağaç, L. Tatar, D. Kısakürek, D. Ülkü, Acta Crystallogr. C 55, 1413 (1999).

[3] L. Tatar, G. Gökağaç, D. Ülkü, Acta Crystallogr. C 56, 668 (2000).

[4] L. Molu, D. Kisakürek, J. Appl. Polym. Sci. 86(9), 2232 (2002).

[5] K. Aydeniz, Keziban, A. M. Onal, D. Kisakurek, Europ. Polymer Journal 37(10), 2017 (2001).

[6] Ö. Şentürk, W. Sultan, Duygu Kisakürek, Reactive and Functional Polymers, 53, 73 (2002).

[7] Enraf-Nonius CAD-4 Express Software. Version 1.1. Enraf-Nonius, Delft, Netherlands (1993).

[8] G. M. Sheldrick, SHELXS97 and SHELXL97. Pro- gram for Crystal Structure Solution and Refinement. University of Göttingen, Germany (1997).

[9] L. J. Farrugia, WinGX. Program for Crystallography Package. J. Appl. Crystallogr. 32, 837 (1999).

[10] L. J. Farrugia, J. Appl. Crystallogr. 30, 565 (1997).

[11] A. L. Spek, Acta Crystallogr. A46, C-34 (1990).

[12] R. M. Silverstein, G. C. Bassler, T. C. Morrill, Spectroscopic Identification of Organic Compounds, John Wiley \& Sons, New York (1991).

[13] G. Gökağaç, L. T. Yıldırım, M. Sonsuz, F. Şen, Crystal Research and Technology, in press (2004).

[14] M. Pulat, G. Çalışkan, Polymer International 48, 228 (1999).

[15] B. J. Hathaway, A. A. G. Tomlinson, Coord. Chem. Rev. 5, 1 (1970). 